\title{
Skeletopy of the intumescentia lumbalis and conus medullaris applied to epidural anaesthesia in Leopardus geoffroyi
}

\author{
P.H.S. Mengue, E.C. Souza, F.C.S. Bernardes, M.M. Montana, R. Thiesen, P. de Souza Junior \\ Laboratory of Animal Anatomy, Federal University of Pampa, Campus Uruguaiana, Brazil
}

[Received: 4 April 2019; Accepted: 4 May 2019]

Background: Leopardus geoffroyi is a Neotropical wild felid with wide distribution in the south of the South American continent. The objective was to investigate the skeletopy of the intumescentia lumbalis (IL) and conus medullaris (CM) from 11 specimens of $L$. geoffroyi collected dead on highways.

Materials and methods: The cadavers were fixed in formaldehyde solution and dissected to allow the dorsal exposure of IL and CM. The cranial and caudal limits were marked with radiopaque pins and radiographic projections were used to determine the skeletopy. The lengths of IL and CM were measured with a pachymeter. Results: In most specimens, the I $L$ was located at the level of $L 4$ and $L 5$ vertebrae, although in 4 (1 male and 3 females) individuals its cranial limit was $L 3$ and in 3 specimens ( 2 male and 1 female) the caudal limit was $L 6$. The length of IL was $35.6 \pm 6.7 \mathrm{~mm}$. The $C M$ had its base predominantly at the level of the $L 5$ vertebra, although in some specimens the base was in $L 4$ and in others in $L 6$. The apex of the $C M$ can be found since the lumbosacral junction until the level of the $\mathrm{Cd} 2$ vertebra. The $C M$ measured $74.4 \pm 14.3 \mathrm{~mm}$.

Conclusions: Based on the skeletopy, it can be suggested that epidural anaesthesia procedures in L. geoffroyi are safer with the introduction of the catheter through the sacrocaudal interarcual space, as recommended by some anaesthetists for the domestic cat. (Folia Morphol 2020; 79, 1: 65-70)

Key words: carnivorans, Geoffroy's cat, spinal cord, wild felids

\section{INTRODUCTION}

The Leopardus geoffroyi (d'Orbigny and Gervais, 1844), also known as Geoffroy's cat [19, 21], is a wild felid that inhabits several regions of South America, such as Uruguay, Bolivia, Chile, Argentina, Paraguay and Brazil $[3,18,21]$. It is an animal with body structure similar to the domestic cat, weighing on average $4 \mathrm{~kg}$. It has a mammal and small rodents-based diet which may include marsupials, birds and other vertebrates [33].

Neuroanatomy studies can facilitate the understanding of free-living species habits [11], subsidise phylogenetic inferences and support veterinary procedures in wild species [12, 32].
The skeletopy of the intumescentia lumbalis (IL) and conus medullaris (CM) are distinct between species and their knowledge is essential for epidural anaesthesia, cerebrospinal fluid collection and performing contrast-enhanced radiographic studies of the vertebral canal $[5,10,11]$. Epidural blockade can be performed in a wide variety of surgical procedures, with the advantages of minimising cardiovascular and respiratory alterations, improve trans and postoperative analgesia and reduce the need of general anaesthetics [20]. These benefits are even more crucial in wildlife medicine due to the complexity of drug administration in the postoperative,

Address for correspondence: Prof. P. de Souza Junior, Laboratory of Animal Anatomy, Rodovia BR-472, Km 595, Uruguaiana, RS, Brazil, Postal code 97501-970, tel/fax: +55 55 3911-0200, e-mail: paulosouza@unipampa.edu.br 


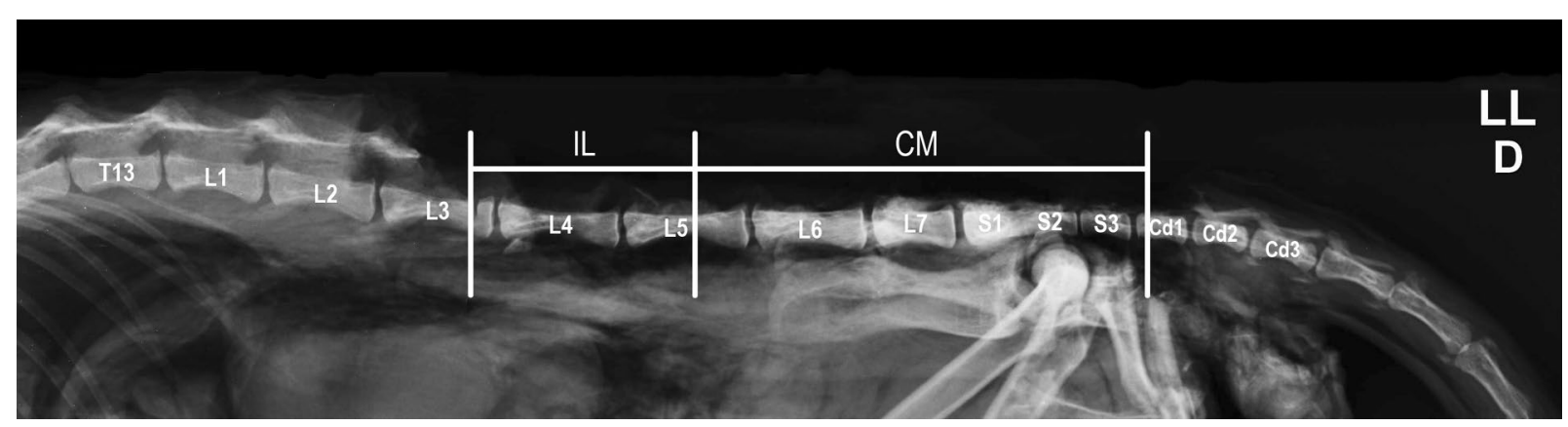

Figure 1. Radiographic image in lateral projection, right lateral decubitus, of the lumbar and sacral region of an adult female specimen of Leopardus geoffroyi after removal of the epaxial muscles, spinal processes and vertebral arches to evidence the skeletopy of intumescentia lumbalis (IL) between L3 to L5 and conus medullaris (CM) between L5 to Cd1.

high frequency of injuries by polytrauma in the pelvic limbs, and patients commonly debilitated at the time of surgery [22].

Although the skeletopy of the CM has already been documented and points out significant differences between domestic and wild species of the Carnivora order, there is still no knowledge when it comes to $L$. geoffroyi $[2,4,8,13-15,23,26,27,30,31]$.

The aim of this study is to report the skeletopy and the dimensions of IL and CM of L. geoffroyi, in order to increase the knowledge in the neuroanatomy of wild carnivores, as well as to support locoregional anaesthetic procedures in this species.

\section{MATERIALS AND METHODS}

Eleven adult cadavers of $L$. geoffroyi were used, 8 females and 3 males, collected dead on highways in the southwestern mesoregion of Rio Grande do Sul (IBAMA authorisation/SISBIO number 33667). Only cadavers that provided good visualisation of the spinal cord in both thoracolumbar and sacral regions were selected for this study. After collection, the cadavers were identified and fixed with aqueous $50 \%$ formaldehyde solution through intramuscular and intracavitary injections and, then, immersed in vats containing $10 \%$ formaldehyde solution for at least 3 weeks before being dissected. To this end, the skin, subcutaneous tissue, epaxial musculature, spinous processes, vertebral arches and ligaments were removed in thoracic caudal regions, lumbar, sacral and proximal of the tail, which allowed the dorsal exposure of IL, CM and terminal filament of the spinal cord. In only 2 specimens, 1 male and 1 female, it was not possible to determine the end of the CM. With the aid of a digital calliper (capacity 0-150 mm, resolution $0.01 \mathrm{~mm}$, accuracy $\pm 0.02 \mathrm{~mm}$, ZAAS Precision, Amatools ${ }^{\circledR}$ ) the following measurements can be obtained:
- length of intumescentia lumbalis (ILL), established as the distance between the cranial and caudal boundaries of intumescence;

- conus medullaris length ( $\mathrm{CML}$ ), established as the distance between the base and apex of the conus;

- intumescentia lumbalis circumference (ILC), established by removing a layer of the dura-mater at the most enlarged point of the intumescentia;

- conus medullaris circumference (CMC), established by removing a layer of the dura-mater at the base of the conus.

The thoracolumbar length (TL), established as the distance between the caudal angle of the scapula to the cranial border of the wing of the ilium, was measured with a flexible tape.

The demarcations of the cranial and caudal limits for the determination of ILL and CML were performed with fine-tipped metal pins and the radiographed cadavers in the lateral-side projection with the Phillips ${ }^{\circledR}$ apparatus, model Aquilla Plus 300. Radiographs were taken in a Kodak ${ }^{\circledR}$ Direct View Computerised cassette system, exposure of $40 \mathrm{KV}, 200 \mathrm{~mA}$ in $0.1 \mathrm{~s}$ and saved in DICOM $^{\circledR}$ format. The visualisation was done using Radiant Dicom Viewer ${ }^{\circledR}$ software version 1.6.8.

The BioEstat $5.3^{\circledR}$ software was used to obtain the descriptive statistics data (standard deviation and arithmetic mean), to perform the Student's t test to compare the means of the measures between sexes and determination of the coefficient $r$ by Pearson's linear correlation between measurements.

\section{RESULTS}

Invariably, the number of lumbar vertebrae was seven and the number of sacral was three. The skeletopy of IL and CM were determined according to radiographic images in the lateral projection (Fig. 1). 


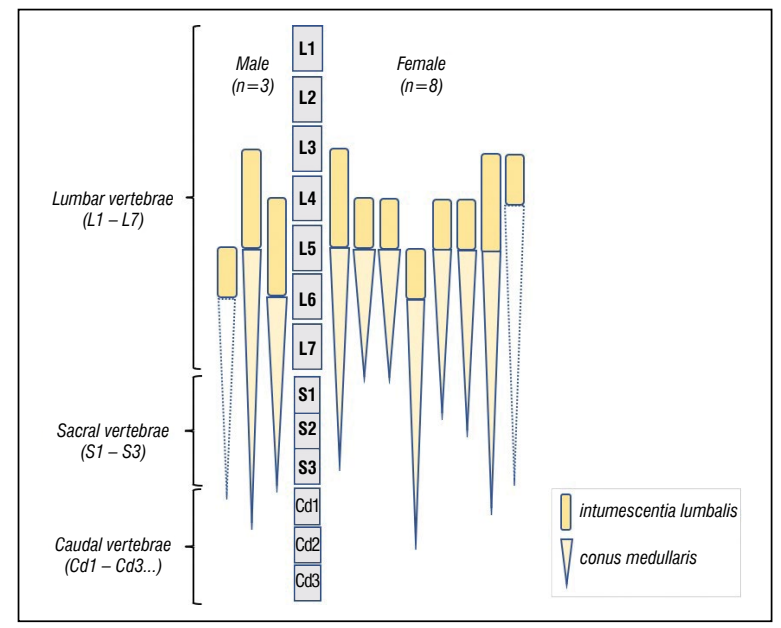

Figure 2. Schematic representation of skeletopy of intumescentia lumbalis and conus medullaris of the 11 specimens of Leopardus geoffroyi. The 2 coni medullaris represented in dotted lines $(1$ male and 1 female) did not have the apex determined.

In most specimens (36\%), IL was located in the vertebral canal between the L4 and L5 vertebrae (Fig. 2). It was also located between L3 and L5 in $28 \%$ of the animals, between $\mathrm{L} 5$ and $\mathrm{L} 6$ in $18 \%$, between $\mathrm{L} 3$ and $L 4$ in $9 \%$ and between $L 4$ and $L 6$ in $9 \%$. Therefore, the $\mathrm{CM}$ had its base always at the level of the $L 5$ vertebra or caudal to this in $91 \%$ of the individuals, except for 1 female in which it started at the height of L4. The point where the apex of the CM originated the terminal filament was located from the level of the vertebrae L7-S1 (22\% of cases) to as caudal as the body of the $\mathrm{Cd} 2$ vertebra (11\%).

The IL had a mean length of $35.6 \pm 6.7 \mathrm{~mm}$ and the CM $74.4 \pm 14.3 \mathrm{~mm}$ (Fig. 3, Table 1), with no significant difference between the averages of the measurements between males and females $(p>0.05)$. The Pearson's linear correlation was highly positive and significant $(p<0.05)$ between ILL and $\mathrm{TL}(r=0.83)$ and moderately positive between CML and TL $(r=0.60)$ and moderately negative between ILC and TL ( $r=-0.61)$. The linear correlation between ILL and CML was poorly negative $(r=-0.230)$.

\section{DISCUSSION}

The existence of seven lumbar vertebrae and 3 sacrals in L. geoffroyi is described for felids [7]. Even though they have small numerical differences in the number of vertebrae of the thoracic and lumbar segments between different species of the same family of the Carnivora order, in the Felidae family this does not occur at all. In the domestic feline population, the

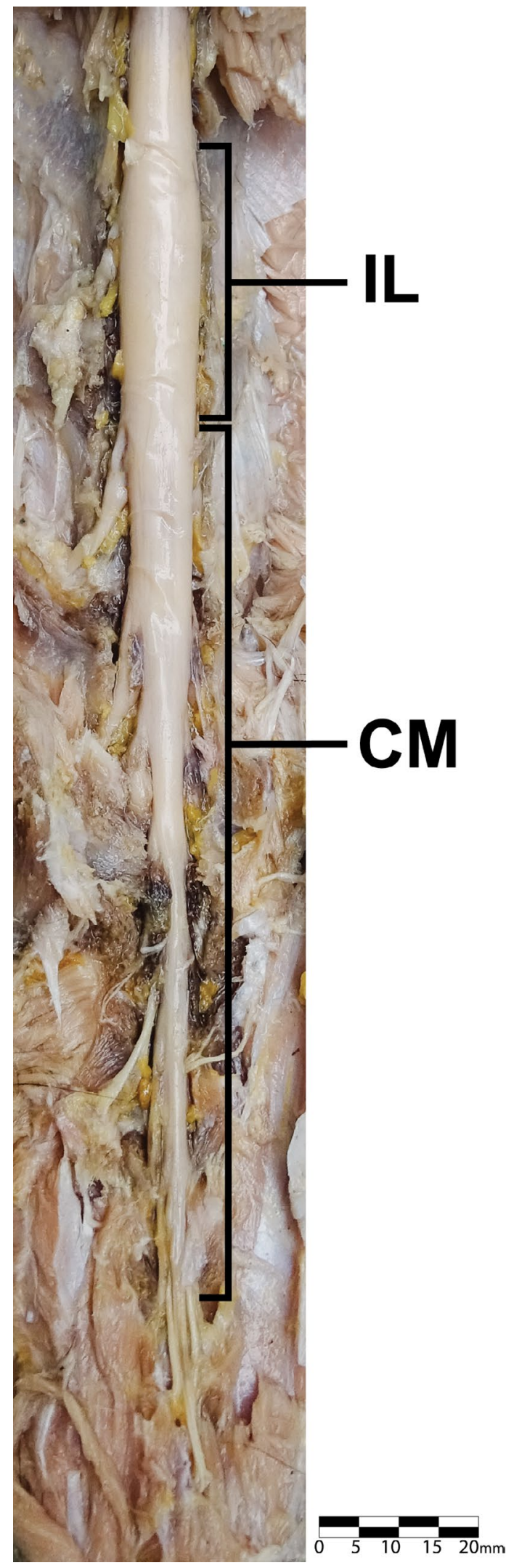

Figure 3. Dorsal view macrophotography of the intumescentia lumbalis (IL) and conus medullaris (CM) of a female Leopardus geoffroyi specimen, after removal of the epaxial muscles, spinal processes and vertebral arches from midlumbar, sacral and caudal regions. Bar: $20 \mathrm{~mm}$. 
Table 1. Arithmetic means and standard deviations of intumescentia lumbalis length (ILL), conus medullaris length (CML), intumescentia lumbalis circumference (ILC), conus medullaris circumference (CMC) and thoracolumbar length (TL) distributed by sex

\begin{tabular}{lccccc}
\hline & ILL $[\mathrm{mm}]$ & CML $[\mathrm{mm}]$ & ILC [mm] & CMC [mm] & TL [cm] \\
\hline General & $35.6 \pm 6.7(\mathrm{n}=11)$ & $74.4 \pm 14.3(\mathrm{n}=9)$ & $21.9 \pm 1.7(\mathrm{n}=11)$ & $15.7 \pm 2.4(\mathrm{n}=10)$ & $25.9 \pm 2.6(\mathrm{n}=10)$ \\
Males & $34.5 \pm 8.5(\mathrm{n}=3)$ & $84.6 \pm 28.3(\mathrm{n}=2)$ & $20.52 \pm 1.9(\mathrm{n}=3)$ & $17.7 \pm 1.9(\mathrm{n}=3)$ & $28.0 \pm 4.4(\mathrm{n}=3)$ \\
Females & $35.9 \pm 6.6(\mathrm{n}=8)$ & $71.4 \pm 9.6(\mathrm{n}=7)$ & $22.6 \pm 1.8(\mathrm{n}=8)$ & $14.7 \pm 2.0(\mathrm{n}=7)$ & $25.0 \pm 1.4(\mathrm{n}=7)$ \\
\hline
\end{tabular}

lumbar, sacral and caudal segments of the spine may exhibit numerical congenital variations with occurrence between $10 \%$ and $20 \%$ [17], which did not appear in the specimens of $L$. geoffroyi of the present study.

The skeletopy of IL predominated at the level of the L4 and L5 vertebrae in 36\% of the cadavers, although it could start as cranial as L3 (36\%) and end as caudal as L6 (27\%). In the Carnivora order, IL extends through the vertebral canal at the level of L4 to $L 6$ in $70 \%$ of the domestic cats [28], between L4 to L7 in domestic dogs [6], T12, L1 and L2 in 3 specimens of Pteronura brasiliensis [15] and L3 to L6 in a cadaver of Atelocynus microtis [26]. Thus, the limits restricted to 2 vertebrae may suggest that IL is somewhat smaller in L. geoffroyi than in other carnivorous species. IL occupied the extension of 2 vertebrae in 3 specimens of Eira barbara (L3-L4) [1], in 2 Procyon cancrivorus (L3-L4) [30] and in 5 specimens of Lycalopex gymnocercus (L4-L5) [31]. Some of these differences may reflect methodological differences in the determination of skeletopy and subjectivity in the visualisation of the swollen area of the spinal cord.

Measurements of IL length of carnivores were only found for $P$. cancrivorus (18 mm) [30], L. gymnocercus (31.4 $\pm 5.1 \mathrm{~mm}$ ) [31] and domestic felines (35 to $40 \mathrm{~mm}$ ) [29]. The average obtained in specimens of $L$. geoffroyi was $35.6 \pm 6.6 \mathrm{~mm}$, relatively similar to what is described for domestic cats, who have similar body mass.

The skeletopy of CM predominated with the base positioned at the level of the L5 vertebra or caudal to it. In only 1 female specimen the base of the conus emerged from L4. The apex was as cranial as the lumbosacral junction and as caudal as $\mathrm{Cd} 2$. The distribution of the CM with its base on the lumbar vertebrae and the apex on the sacrals was described in different carnivores: in felids, between L6 and S2 in a Harpailurus yagouaroundi [4] and in domestic felines [29] and between L4 and S3 in a Leopardus pardalis [2]; in canids, between L6 and S3 in a Cerdocyon thous [23], L7 and S3 and in a A. microtis [26] and
L5 and S3 in 5 L. gymnocercus [31]; in the procionid Nasua nasua was reported between L5 and S3 in 3 individuals [8]. In some species of the Caniformia suborder, the CM limited to lumbar vertebrae, such as L3 to L7 in domestic dogs [27], L3 to L6 in 5 Chrysocyon brachiurus [13], in $3 P$ brasiliensis [15], L4 to L6 in 3 Eira barbara [1] and L4 to L7 in 2 P. cancrivorus [31].

Therefore, the skeletopy of the conus medullaris of $L$. geoffroyi follows an elongated pattern caudally, as extensively documented in felids. The apex of CM reached even the first caudal vertebrae in at least $3(27 \%)$ specimens, which is not mentioned in other carnivorous species studied.

In addition to the constancy in the number of 7 lumbar vertebrae, in felids the apex of the CM extends to the last sacral vertebrae, as in the case of domestic felines [29], H. yagouaroundi [4], L. pardalis [2] and confirmed in the present study with $L$. geoffroyi. It is possible that a longer spinal cord caudally is advantageous to group peripheral neural tissue close to the pelvic and tail limbs, regions of recognised versatility in felids.

The average CML in L. geoffroyi $(74.4 \mathrm{~mm}$ ) was only inferior than what is described in C. thous (101.3 mm) [23] and L. pardalis [2] and higher than the $A$. australis $(43 \mathrm{~mm})$ [14], P. brasiliensis (55 mm) [15], $H$. yagouaroundi $(50 \mathrm{~mm}$ ) [4], in $N$. nasua (52 to $55 \mathrm{~mm}$ ) [8], A. microtis (39 mm) [26], E. barbara (43.1 mm) [1], P. cancrivorus (53.5 mm) [30] and L. gymnocercus $(68.8 \mathrm{~mm}$ ) [31]. The CML average was $50.8 \mathrm{~mm}$ in 30 domestic felines [29], Although some individuals present conus up to $80 \mathrm{~mm}$ in length. However, it would be desirable to establish indexes for comparison purposes proportional to the size [31].

The linear correlation between ILL and CML was poorly negative $(r=-0.230)$, as in $L$. gymnocercus ( $r=-0.227$ ), suggesting that the CML is greater to compensate for a relatively shorter ILL when compared to other species. In fact, CML correlated better with TL than ILL.

From the applied standpoint, there are few reports of the use of epidural anaesthesia in wild felids. Some 
authors affirm that the technique may be identical to the one used in domestic felines, positioning the needle in the space between the L7 and S1 vertebrae [9]. The lumbosacral space was also chosen to perform epidural anaesthesia in 6 wild cats, of different species, as adjuvant to general anaesthesia for ovariohysterectomy due to pyometra [16]. However, the dissection of $L$. geoffroyi specimens allowed inferring that, the epidural anaesthesia procedure tends to be safer if the catheter is inserted into the sacrocaudal interarcual space ( $\mathrm{S} 3-\mathrm{Cd} 1)$, although it can also be introduced into the interarcual space between $\mathrm{L6}-\mathrm{L7}$ or lumbosacral (L7-S1). Since the apex is the thinner part of CM, its position inside the sacral canal turns the sacrocaudal space safer to puncture. This finding is similar to what is recommended in domestic felines [29].

Due to the anatomical similarity of IL and CM, the techniques of contrast-enhanced myelography and CSF collection in the lumbar region of $L$. geoffroyi can be performed with the introduction of the catheter into the interarcual space between L5-L6 or L6-L7, as recommended for domestic felines $[11,19,24]$.

\section{CONCLUSIONS}

The result of the dissections suggests that epidural anaesthesia in $L$. geoffroyi can be performed both through the sacrocaudal or lumbosacral interarcual spaces, but the former might be a safer choice, since the apex of CM may extend caudally to the level of the second caudal vertebrae in some individuals.

\section{Acknowledgements}

Acknowledgements to Academic Development Programme (PDA) of the Federal University of Pampa.

\section{Funding}

This study was financed in part by the Coordenação de Aperfeiçoamento de Pessoal de Nível Superior - Brasil - CAPES - Finance code 01.

\section{REFERENCES}

1. Branco É, Lins F, Pereira L, et al. Topografia do cone medular da irara (Eira barbara) e sua relevância em anestesias epidurais. Pesq Vet Bras. 2013; 33(6): 813-816, doi: 10.1590/s0100-736x2013000600020.

2. Brígida SSS, Branco E, Pinheiro LL, et al. Topografia do cone medular da jaguatirica (Leopardus pardalis). Acta Vet Bras. 2010; 4(1): 51-54.

3. Cabrera, A. Catálogo de los mamíferos de América del Sur. Revista del Museo Argentino de Ciencias Naturales "Bernardino Rivadavia", Zoología. 1957; 4: 1-370.
4. Carvalho SFM, Santos ALQ, Avila Junio RH, et al. Topografia do cone medular em um gato mourisco, Herpailurus yagouaroundi (Severtzow, 1858) (Felidae). Arch Vet Scien. 2003; 8(2): 35-38, doi: 10.5380/avs.v8i2.4031.

5. Dyce KM, Sack WO, Wensing CJG. Tratado de Anatomia Veterinária. 4th ed. Elsevier, Rio de Janeiro 2010.

6. Evans HE, Lahunta A. Guide to the Dissection of the Dog. 7th ed. Saunders Elsevier, Missouri 2010.

7. Ewer RF. The Carnivores. Cornell University Press, Ithaca 1973.

8. Gregores GB, Branco E, Carvalho AF, et al. Topografia do cone medular do quati (Nasua nasua Linnaeus, 1766). Biotemas. 2010; 23(2): 173-176.

9. Gunkel C, Lafortune M. Felids. In: West G, Heard D, Caulkett N (Eds.) Zoo and Wildlife Immobilization and Anesthesia. 1st ed. Blackwell Publishing, Ames 2007: 443-459.

10. Hopkins GS. The correlation of anatomy and epidural anesthesia in domestic mammals. Cornell Veterinarian. 1935; 25: 263-270.

11. Lahunta A, Glass $E$, Kent M. Veterinary Neuroanatomy and Clinical Neurology. 4th ed. Elsevier Saunders, St. Louis 2015.

12. Lima F, Santos A, Lima B, et al. Topographic anatomy of the spinal cord and vertebromedullary relationships in Mazama gouazoubira Fisher, 1814 (Artiodactyla; Cervidae). Acta Scientiarum. Biological Sciences. 2010; 32(2), doi: 10.4025/actascibiolsci.v32i2.5061.

13. Machado G, Fonseca C, Neves M, et al. Topografia do cone medular no lobo-guará (Chrysocyon brachyurus Illiger, 1815). Revista Brasileira de Ciência Veterinária. 2001; 9(2): 107-109, doi: 10.4322/rbcv.2015.240.

14. Machado GV, Lesnau GG, Birck AJ. Topografia do cone medular no lobo marinho (Arctocephalus australis Zimmermann, 1783). Arquivos Ciências Veterinárias e Zoologia da Unipar. 2003; 6(1): 11-14.

15. Machado GV, Rosas FCW, Lazzarini SM. Topografia do cone medular na ariranha (Pteronura brasiliensis Zimmermann, 1780). Ciência Animal Brasileira. 2009; 10(1): 301-305.

16. McCain S, Ramsay Ed, Allender MC, et al. Pyometra in captive large felids: a review of eleven cases. J Zoo Wildl Med. 2009; 40(1): 147-151, doi: 10.1638/2008-0008.1, indexed in Pubmed: 19368254.

17. Newitt A, German AJ, Barr FJ. Congenital abnormalities of the feline vertebral column. Vet Radiol Ultrasound. 2008; 49(1): 35-41, doi: 10.1111/j.1740-8261.2007.00314.x, indexed in Pubmed: 18251292.

18. Oliveira TG, Cassaro K. Guia de campo dos felinos do Brasil. Instituto Pró-carnívoros. Fundação Parque Zoológico de São Paulo, São Paulo. 2005.

19. Pardo AD, Morgan JP. Myelography in the Cat. Veterinary Radiology. 1988; 29: 89-95.

20. Pascoe PJ. Advantages and guidelines for using epidural drugs for analgesia. Vet Clin North Am Small Anim Pract. 1992; 22(2): 421-423, doi: 10.1016/s01955616(92)50657-x, indexed in Pubmed: 1585592.

21. Pereira J, Lucherini M, Trigo T. 2015. Leopardus geoffroyi. The IUCN Red List of Threatened Species 2015: e.T15310A50657011. http://dx.doi.org/10.2305/IUCN. UK.2015-2.RLTS.T15310A50657011.en (Downloaded on 31 March 2019). 
22. Pessutti C, Santiago MEB, Oliveira LTF. Medicine and Surgery of South American Wild Animals. Iowa State University Press, Ames 2001.

23. Pinheiro LL, Lima AR, Souza ACB, et al. Topografia do cone medular do cachorro-do-mato (Cerdocyon thous Linnaeus, 1766): relato de caso. Biotemas. 2011; 22(4): 129-133.

24. Roberts RE, Selcer BA. Myelography and epidurography. Vet Clin North Am Small Anim Pract. 1993; 23(2): 307-329, doi: 10.1016/s0195-5616(93)50030-x, indexed in Pubmed: 8465493

25. Randau M, Goswami A. Morphological modularity in the vertebral column of Felidae (Mammalia, Carnivora). BMC Evolutionary Biology. 2017; 17(1), doi: 10.1186/s12862017-0975-2.

26. Saldanha KL, Branco E, Lima AR. Topografia do cone medular do cachorro-do-mato-de-orelhas-pequenas (Atelocynus microtis Sclater, 1882): relato de caso. Biotemas. 2011; 24(4): 135-139.

27. Santiago W. Esqueletopia do cone medular em Canis familiaris. Arquivos da Universidade Federal Rural do Rio de Janeiro. 1974; 4(1): 67-69.

28. Silva PHC, Silva RM, Lima EMM. Topografia das intumescências cervical e lombar em gatos sem raça definida (Felis catus Linnaeus, 1758). Ciência Animal Brasileira. 2008; 9(4): 1089-1095.

29. Silva P, Silva RM, Lima E. Topografia do cone medular em gatos sem raça definida. Arquivo Brasileiro de Medicina Veterinária e Zootecnia. 2009; 61(5): 1062-1066, doi: 10.1590/s0102-09352009000500008.

30. Souza DR, Ferreira LS, Pereira DKS, et al. Topografia do cone medular de Procyon cancrivorus. Bioscience J. 2014; 30(3): 823-829.

31. Souza Junior $P$, Mattos $K$, Carvalho $N$, et al. Topografia da intumescência lombar e do cone medular em Lycalopex gymnocercus (G. Fischer, 1814). Revista Brasileira de Ciência Veterinária. 2014; 21(3): 173-177, doi: 10.4322/ rbcv.2014.380

32. Souza Junior $P$, Carvalho NC, Mattos $K$, et al. Brachial plexus in the pampas fox (lycalopex gymnocercus): a descriptive and comparative analysis. Anat Rec (Hoboken). 2017; 300(3): 537-548, doi: 10.1002/ar.23509, indexed in Pubmed: 27788289.

33. Ximenez, A. Notas sobre Felidos Neotropicales VIII. Observaciones sobre el contenido estomacal y el comportamiento alimentar de diversas espécies de Felinos. Revista Nordestina de Biologia. 1982; 5(1): 89-91. 